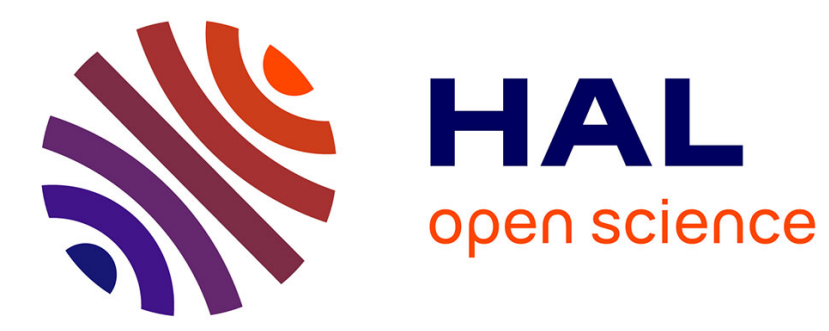

\title{
Incentivizing organ donation through a nonmonetary posthumous award
}

Mascia Bedendo, Linus Siming

\section{To cite this version:}

Mascia Bedendo, Linus Siming. Incentivizing organ donation through a nonmonetary posthumous award. Health Economics, 2019, 10.1002/hec.3943 . hal-02315010

\section{HAL Id: hal-02315010 \\ https://hal-audencia.archives-ouvertes.fr/hal-02315010}

Submitted on 14 Oct 2019

HAL is a multi-disciplinary open access archive for the deposit and dissemination of scientific research documents, whether they are published or not. The documents may come from teaching and research institutions in France or abroad, or from public or private research centers.
L'archive ouverte pluridisciplinaire $\mathbf{H A L}$, est destinée au dépôt et à la diffusion de documents scientifiques de niveau recherche, publiés ou non, émanant des établissements d'enseignement et de recherche français ou étrangers, des laboratoires publics ou privés. 
Incentivizing organ donation through a non-monetary posthumous award

\author{
Mascia Bedendo ${ }^{\mathrm{a}, *} \quad$ Linus Siming $^{\mathrm{a}}$ \\ ${ }^{a}$ Audencia Business School, Nantes, France
}

\begin{abstract}
Since 2013, The Order of St John Award for Organ Donation is offered to the families of deceased solid organ donors in the United Kingdom to honor the donors and inspire others to donate. We evaluate the effects of this award using a difference-in-differences approach that builds on the fact that solid organ donors are eligible for the award, while cornea-only donors are not. We find that the introduction of the award led to an increase in the number of deceased solid organ donors, as well as in the general willingness to register as solid organ donors when alive.
\end{abstract}

JEL classification: I18

Keywords: Organ donation; incentives for organ donation; posthumous awards

\footnotetext{
* Correspondence to: Audencia Business School, 8 route de la Jonelière, 44312 Nantes, France. Email: mbedendo@audencia.com, Phone: +33(0)240373434. We thank participants at the American-European Health Economics Study Group in Cambridge, Massachusetts, for their helpful comments and Cathy Hopkinson from National Health Service Blood and Transplant for assisting with data collection. This work has not received any funding and we do not have any conflict of interest to declare.
} 


\section{INTRODUCTION}

In 2013, the Order of St John together with the National Health Service (NHS) Blood and Transplant introduced The Order of St John Award for Organ Donation in the United Kingdom. This non-monetary award, which takes the form of a pin badge and a scroll, is given to the families of deceased solid organ donors as recognition of the generosity of the donor at public award ceremonies. An additional explicitly stated purpose of the award is to raise awareness of the importance of solid organ donation and inspire others to follow in the honored donors' footsteps (NHS-St John, 2016). To the best of our knowledge, this award represents the first nationwide official recognition for deceased organ donors in any country. Previous awards have either been ad hoc in nature or granted by individual hospitals (Gardiner and Denby, 2015).

We use the introduction of the award to study the incentivizing effects of posthumous recognition on organ donation. There is ample theoretical ground for believing that awards can spur solid organ donation among both living and deceased potential donors. Niederle and Roth (2014) survey a representative sample of adults in the United States to collect approval rates of various policies that reward living kidney donors. They find that a policy that rewards a kidney donor with a medal of heroism and a monetary prize (provided by a private foundation rather than taxpayers) has the significantly highest approval. Woodfine and Redelmeier (2014) argue that an increased level of nonmonetary public recognition of the family members of deceased organ donors in the United States could inspire others in the community to consent to organ donation.

To estimate to what extent posthumous non-monetary public recognition initiatives can incentivize solid organ donation, we use a difference-in-differences approach around the 
introduction of The Order of St John Award for Organ Donation. We have natural treatment and control groups since this award is given only to commemorate those who donated solid organs-e.g. heart, kidneys, liver, lungs or pancreas - whereas tissue donation and eye-only donation (cornea) are not recognized under this scheme. While cornea and tissue transplantations can have a dramatic effect on a patient's quality of life, they are not considered lifesaving (Gaum et al., 2012) and, as such, were not included in this award scheme. Accordingly, in our analysis, the treatment group consists of deceased donors of solid organs and the control group consists of deceased donors of cornea who did not donate any solid organ. Our difference-in-differences analysis suggests that the award has produced two important effects: An increase in the number of deceased solid organ donors and an increase in the willingness to donate solid organs among the population that has registered as donors.

Our results contribute to the literature on successful policy incentives put in place to increase the supply of transplantable organs. Stoler et al. (2017) include a recent overview of such policies, which for example include systems where individuals are considered organ donors unless they actively opt out (Horvat et al., 2010), priority schemes for registered organ donors (Kessler and Roth, 2012, 2014), financial compensation to the donor or the donor's family (Friedman, 2006), and organ exchange (Roth et al., 2004). Understanding which policies can spur organ donation is of course important beyond the academic discourse, as there is a global shortage of organs (Stoler et al., 2017). Our study also contributes to the literature on the incentivizing effects of official non-monetary awards. A growing number of empirical papers have documented that a bestowing body can push individuals to outperform along desired dimensions through awards. For example, Ager et al. (2018) find that bravery awards can trigger 
fighter pilots to take more risks in combat while Raff and Siming (2016) show that governments can use knighthoods to induce business leaders to uphold an excessive number of employees. This study contributes to the literature on honors and awards by being the first to show that even posthumous awards can have an incentivizing effect in increasing the output targeted by the bestowing body.

\section{INSTITUTIONAL BACKGROUND}

Currently, organ donation in the United Kingdom is conducted through an opt-in system. ${ }^{1}$ An individual who wishes to donate her organs can register with the NHS Organ Donor Register. The family members of a registered donor will be consulted after the person's death to ensure that she had not changed her mind after registration and to give their final consent to the organ donation. The United Kingdom organ donation legislation states that consent lies with the deceased, but, in practice, relatives' wishes are respected if they do not consent to the organ donation (Vincent and Logan, 2012). The family's consent is also sought in case the deceased was not registered as a donor. According to the NHS Blood and Transplant Organ Donation and Transplantation Activity Report, as of $2017,36 \%$ of the population had registered as donors and the average family consent rate to organ donations was equal to $63 \%{ }^{2}$

\footnotetext{
${ }^{1}$ Since December 2015, Wales operates under a presumed consent system (soft opt-out) where deceased adults are deemed to have consented to organ donation unless they had positively opted out before their death. We will account for this in our empirical analysis. Changes to an opt-out system are currently (October 2018) under discussion in both the British and Scottish Parliaments.

${ }^{2}$ Available from http://www.odt.nhs.uk/statistics-and-reports/annual-activity-report/.
} 
In December 2006, The Government set up the Organ Donation Taskforce to recommend actions needed to increase organ donation. As one of the recommendations, the taskforce in 2008 called for appropriate ways of recognizing individual donors (Organ Donation Taskforce, 2008). Subsequently, in 2013, the Order of St John-an order of Chivalry which is also the United Kingdom's leading provider of first-aid services - entered into a partnership with NHS Blood and Transplant—who has the country's public responsibility for optimizing the supply of blood, organs, and tissuesto launch The Order of St John Award for Organ Donation. The award is intended to not only honor donors, but also raise awareness of organ donation and inspire other families to follow the donors' example by becoming donors themselves (NHS-St John, 2016).

The award, which is depicted in Figure 1, is wearable in the form of a pin and is offered by invitation to all families in the United Kingdom whose relative donated a solid organ after death. The award is open to people of all faiths or no faith. The concept of the award was modeled on The Elizabeth Cross (Gardiner and Denby, 2015), which is a posthumous award given to the next of kin of members of the British Armed Forces killed in action. The Order of St John Award for Organ Donation, together with a scroll, is awarded posthumously to donors and accepted on their behalf by relatives at an official regional ceremony. In 2014, $65 \%$ of the families of deceased solid organ donors accepted the offer to participate to the ceremony and receive the award. Those ceremonies have generally attracted a significant level of media publicity. ${ }^{3}$

\footnotetext{
${ }^{3}$ Information from http://odt.nhs.uk/pdf/advisory_group_papers/NODC/Order_of_St_John_Award_for_ organ_Donation_Report.pdf accessed on 7 December, 2017.
} 


\section{METHOD}

To analyze if a non-monetary posthumous award can incentivize organ donation we gather data on deceased solid organ and cornea-only donors in the United Kingdom over the years 2010 to 2017 from the annual issues of the NHS Blood and Transplant Organ Donation and Transplantation Activity Reports. ${ }^{4}$ The treatment group consists of deceased donors where at least one solid organ was recovered for the purpose of transplantation and the control group consists of deceased donors where only corneas were recovered for the purpose of transplantation. Some of the donors in the treatment group may have also donated their corneas, but none of the donors in the control group donated a solid organ. We therefore refer to the treatment (control) group as solid organ (cornea-only) donors. We use the data to estimate the following model of deceased donors:

$$
Y_{t, i}=\text { Post award }+ \text { Treatment group }+d(\text { Treatment group } \times \text { Post award })+e_{t, i}
$$

where $Y_{t, i}$ is the natural logarithm of deceased donors during year $t$ in group $i$. The two groups $i$ are the treatment and control groups. For the treatment (control) group $Y$ is the $\log$ of the number of deceased solid organ (cornea-only) donors from 1 April to 31 March in each year. The first year in which the award is in place is the one ending on 31 March 2014. The period-specific dummy variable Post award measures the common shocks to the two groups in the pre-award and post-award periods. It is an indicator variable that takes the value of one for each year that the award system is in place (2014, 2015, 2016, and 2017), and zero otherwise (2010, 2011, 2012, and 2013). Thus,

\footnotetext{
4 Available from http://www.odt.nhs.uk/statistics-and-reports/annual-activity-report/ accessed on 7 December, 2017. Data on soft tissue other than cornea are not available.
} 
Post award controls for nation-wide shocks and trends that shape the dependent variables over time in the United Kingdom, such as the overall number of deceased individuals, general medical progress or general health-care policy changes. ${ }^{5}$ The dummy variable Treatment group, which equals one for solid organ donors and zero for cornea-only donors, accounts for time-invariant differences in the number of donations due to group-specific factors. By including these indicator variables in the model, all of the common time variation and the cross-sectional variation across groups are removed.

The interaction Treatment group $\times$ Post award is an indicator variable that takes the value of one for the treatment group for each year that the award system is in place (i.e., after year 2013), and zero otherwise. Thus, the coefficient $d$ is the difference-indifferences estimator that measures the change in the outcome variable stemming from the introduction of The Order of St John Award for Organ Donation. This estimator shows the changes in the number of solid organ donors following the introduction of the award, controlling for changes in the dependent variable among cornea-only donors, which are unaffected by the award.

\section{RESULTS AND DISCUSSION}

\subsection{Impact on solid organ donations}

\footnotetext{
${ }^{5}$ For example, in addition to the recommendation of granting appropriate recognition to individual donors, the Organ Donation Taskforce issued 12 suggestions (Organ Donation Taskforce, 2008) regarding funding, organizational improvements, data monitoring, training of donation teams, increasing awareness among medical staff and the general public. While several of the suggestions were implemented, none of them focused solely on solid organ or cornea donation. Therefore, we expect their effects to be captured by this period dummy.
} 
In Figure 2 we plot the number of deceased solid organ and cornea-only donors by year. The upper panel shows the raw number of deceased donors while the lower panel shows normalized values with year 2010 as the start year. We first note that the number of solid organ donors is lower than the number of cornea-only donors throughout the sample period. Importantly, while the trends up to the introduction are similar for both groups, we note a diverging pattern in the number of donors after the introduction of the award, as only solid organ donors continue to increase from that point onwards. An important assumption of specification (1) is that the error term $e_{t, i}$ is uncorrelated with the time period and the group indicator variables. Essentially, the trend in terms of number of solid organ donors should not differ from the trend in terms of number of cornea-only donors before the award is introduced. The plot in Figure 2 suggests that this is indeed the case, which confirms the appropriateness of using deceased corneaonly donors as a control group.

The first column of Table 1 shows the estimates of the difference-in-differences model (1). The coefficient of the interaction term Treatment group $\times$ Post award represents the increase in the logarithmic outcome variable for a change in the indicator variable from zero to one. Hence, the estimated coefficient of 0.222 translates into a change of $100 \times$ $\left(\exp ^{0.222}-1\right)$, or an increase of $25 \%$ in deceased solid organ donors over the years 2014 to 2017 with respect to the change in cornea-only donors. The coefficient is significant at the $5 \%$ level. This estimate suggests that the award has a large positive impact on the supply of solid organs from deceased donors. 
As mentioned in Section 2, Wales operates under a presumed consent system since December 2015. To ensure that the results are not driven by this change, we re-estimate regression (1) after removing all observations that relate to Wales and report the estimates in the second column of Table $1 .{ }^{6}$ The estimated coefficient for the interaction term Treatment group $\times$ Post award of 0.226 translates into an increase of $25 \%$ in deceased solid organ donors after the introduction of the award compared to the change in cornea-only donors. The coefficient is significant at the $5 \%$ level. We conclude that the 2015 change in the Welsh organ donation system cannot explain away our main findings.

In order to argue that the introduction of the award has played a significant role in explaining the relative increase in solid organ donations, we have to rule out alternative channels. The most plausible competing explanation is medical progress in solid organ retrieval. Compared to solid organs, cornea retrieval for transplantation is considerably easier due to the longer post-mortem time span over which the organ can be recovered (hours or days for corneas versus minutes for solid organs), a less complicated recovery procedure and a longer life span of the organ between retrieval and transplant (see Guam et al., 2012; Osband et al., 2016). Under the hypothesis that, upon either brain or circulatory death, individuals are screened for potential donation of any type of organ (solid or cornea), medical progress in solid organ retrieval in the Post award period would likely translate into a redistribution of donors from cornea-only (control group) to solid organs (treatment group, which includes donors of solid organs and cornea).

\footnotetext{
${ }^{6}$ The number of deceased Welsh cornea-only donors is missing from the activity report of 2017. The NHS Blood and Transplant kindly provided us with the number of corneas donated in that year by type of donor and geographical area, from which we were able to estimate the missing observation.
} 
To assess whether this could drive our findings, we retrieve information on the donation process of solid organs from the annual NHS Blood and Transplant Organ Donation and Transplantation Activity Reports. The first step of the process is the identification, made by clinicians, of eligible donors, i.e. patients for whom death was confirmed following neurological tests (for brain death) or who had treatment withdrawn (for circulatory death) and had no absolute medical contraindications to solid organ donation. Once eligible donors are identified, specialized clinical staff is expected to approach the family of the deceased to ask for consent to organ donation. If family consent is granted, the retrieval of solid organs can take place. Table 2 shows the average percentage of success at each step of the donation process over the periods before (Pre award) and after (Post award) the introduction of the award, i.e. the proportion of eligible donors over audited deaths, the proportion of eligible donors whose family was approached for donation, the family consent rate, and the percentage of cases where solid organs were successfully retrieved following family consent. ${ }^{7}$

If medical progress played a crucial role in driving up the number of solid organ donors Post award, we would expect the proportion of eligible donors over audited deaths and, most importantly, the percentage of successful donations over donors for which consent was granted, to increase substantially in the second period compared to the first. However, we record a modest increase (from $14.3 \%$ to $15.8 \%$ ) in the first indicator and a slight decrease (from $68.7 \%$ to $68.1 \%$ ) in the second. Instead, we observe an important increase (from $56.6 \%$ to $60.4 \%$ ) in the family consent rate to solid organ

\footnotetext{
${ }^{7}$ The average over the Pre award period is computed over three years (2011, 2012 and 2013) as the procedure for recording information on the donation process changed in 2010 , and data for that year are not directly comparable.
} 
donation, which is the only step in the process directly affected by the award scheme. Unfortunately, separate consent rates for solid organ and cornea-only donations are not available, hence we cannot perform a difference-in-differences analysis of consent rates around the introduction of the award. Given that there is no indication from Table 2 that medical advances in the retrieval of solid organs may have significantly contributed to narrowing the gap with respect to cornea retrieval, the relative increase in solid organ donations compared to cornea-only donations likely stems from an increase in the consent rate for the former compared to the latter, which is consistent with the incentives provided by the award.

\subsection{Impact on organ donor registrations}

We further examine the incentivizing role of the Order of St John Award for Organ Donation by investigating if the willingness - when alive - to opt in the NHS Organ Donor Register to donate solid organs has been affected by the award. As described in Section 2, organ donation in the United Kingdom is currently conducted through an optin system. However, a number of those who opt in are restricted donors, i.e. unwilling to donate one or more specific organs. Naturally, any donor unwilling to donate one or more solid organs has a reduced probability of receiving the award. If the award spurs the willingness to donate solid organs, we would expect a reduction in the number of restrictions that relate to solid organs among the registered donors, compared to those that relate to corneas.

We gather data on the restrictions towards solid organ and cornea donations in the United Kingdom over the years 2010 to 2017 from the annual issues of the NHS Blood 
and Transplant Organ Donation and Transplantation Activity Reports. The average percentage of unrestricted donors (out of all individuals registered in the National Organ Register) is $88 \%$. When we look closer at the unwillingness to donate specific organs, some interesting patterns emerge. Figure 3 plots the percentage of donors who are not prepared to donate a specific organ, for each year in our sample period. We observe two patterns when we look at the trends before and after the introduction of the award: While there is a slightly increasing trend in donors who specifically opt out of cornea donations, the trends for donors who refuse to donate one of the solid organs are mostly downward sloping. In Table 3, we formally test these trends. We employ the same estimation strategy as in (1) in a set of repeated difference-in-differences regressions where the control group is always the natural logarithm of all living registrants not prepared to donate their corneas, but where the treatment group is, in turn, the natural logarithm of all living registrants not prepared to donate their kidneys, pancreas, heart, lungs, and liver, respectively. As before, all data relate to the year from 1 April to 31 March, standard errors are corrected for heteroscedasticity, period- and group-specific dummy variables are employed, and the key variable of interest is the interaction between the treatment group and the period after the award was introduced.

We see from Table 3 that the coefficient of the interaction term, Treatment group $\times$ Post award, is negative and statistically significant for pancreas, heart and liver, suggesting that the unwillingness to donate any of these solid organs has decreased compared to the unwillingness to donate corneas after the introduction of the award. The interaction coefficient for kidneys and lungs is also negative, but not statistically significant. We interpret the findings reported in Table 3 as an indication that the introduction of the award overall spurred an increased willingness to register to become solid organ donors. 
The effect is however weaker compared to the direct impact estimated on actual solid organ donations.

\section{CONCLUSION}

Using the 2013 introduction of The Order of St John Award for Organ Donation in the United Kingdom, we are able to make an important contribution to the literature on policies that can incentivize organ donation. We show that the introduction of the award has led to an increase in the number of deceased solid organ donors and, to a lesser extent, in the willingness to register as solid organ donors.

Our results suggest that it is possible to incentivize organ donation through schemes of official recognition of the deceased donor. Consequently, policy makers outside the United Kingdom may want to consider establishing official awards for organ donation in a spirit similar to The Order of St John Award for Organ Donation as a means, among others, of reducing the current shortage of transplantable solid organs. 


\section{REFERENCES}

Ager P, Bursztyn L, Leucht L, Voth H-J (2018) Killer incentives: Relative position, performance and risk-taking among German fighter pilots, 1939-45. NBER working paper 22992.

Friedman AL (2006) Payment for living organ donation should be legalised. British Medical Journal, 333(7571):746-748.

Gardiner D, Denby P (2015) The Order of St John Award for organ donation. Blood and Transplant Matters 45:25-26.

Gaum L, Reynolds I, Jones MNA, Clarkson AJ, Gillan HL, Kaye SB (2012) Tissue and corneal donation and transplantation in the UK. British Journal of Anaesthesia, 108(S1):i43-i47.

Horvat LD, Cuerden MS, Kim J, Koval JJ, Young A, Garg AX (2010) Informing the debate: rates of kidney transplantation in nations with presumed consent. Annals of Internal Medicine, 153(1):641-649.

Kessler JB, Roth AE (2012) Organ allocation policy and the decision to donate, American Economic Review, 102(5):2018-2047.

Kessler JB, Roth AE (2014) Getting more organs for transplantation, American Economic Review Papers and Proceedings, 104(5):425-430.

NHS-St John (2016) Order of St John ceremonies, frequently asked questions and answers. Order of St John, London, United Kingdom.

Niederle M, Roth AE (2014) Philanthropically funded heroism awards for kidney donors? Law and Contemporary Problems, 77(131):131-144. 
Organ Donation Taskforce (2008) Organs for transplants: A report from the Organ Donation Taskforce. Department of Health Publications, London, United Kingdom.

Osband, AJ, James, NT, Segev, DL (2016) Extraction time of kidneys from deceased donors and impact on outcomes. American Journal of Transplantation 16:700-703.

Raff K, Siming L (2016) Knighthoods, damehoods and CEO behaviour, Journal of Corporate Finance, forthcoming.

Roth AE, Sönmez T, Ünver MU (2004) Kidney exchange. Quarterly Journal of Economics, 119(2):457-488.

Stoler A, Kessler JB, Ashkenazi T, Roth AE, Lavee J (2017) Incentivizing organ donor registrations with organ allocation priority, Health Economics, 26:500-510.

Vincent, A, Logan L (2012) Consent for organ donation, British Journal of Anaesthesia, 108(S1):i80-i87.

Woodfine JD, Redelmeier DA (2014) New thinking about honor and deceased organ donation. The American Journal of Medicine, 127(9):802-803. 
Figure 1. The Order of St John Award for Organ Donation

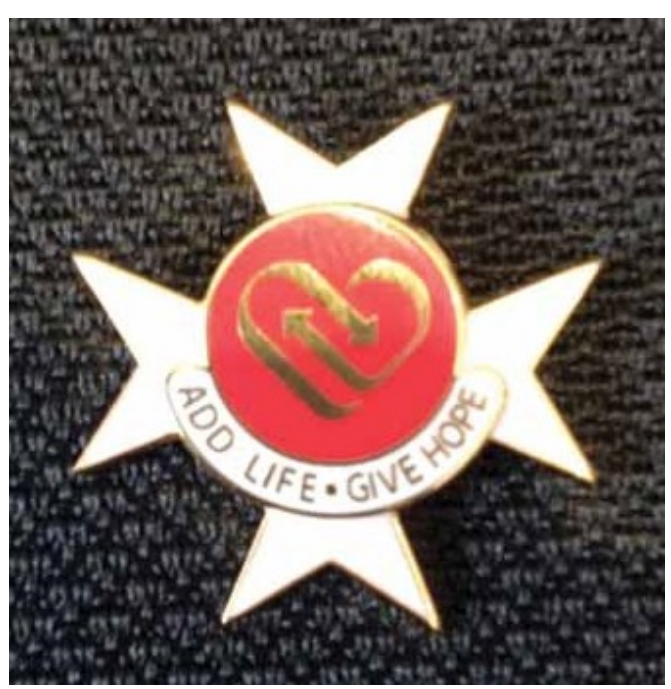

Notes. Picture of The Order of St John Award for Organ Donation obtained from Gardiner and Denby (2015), p. 26. 
Figure 2. Deceased Donors per Year
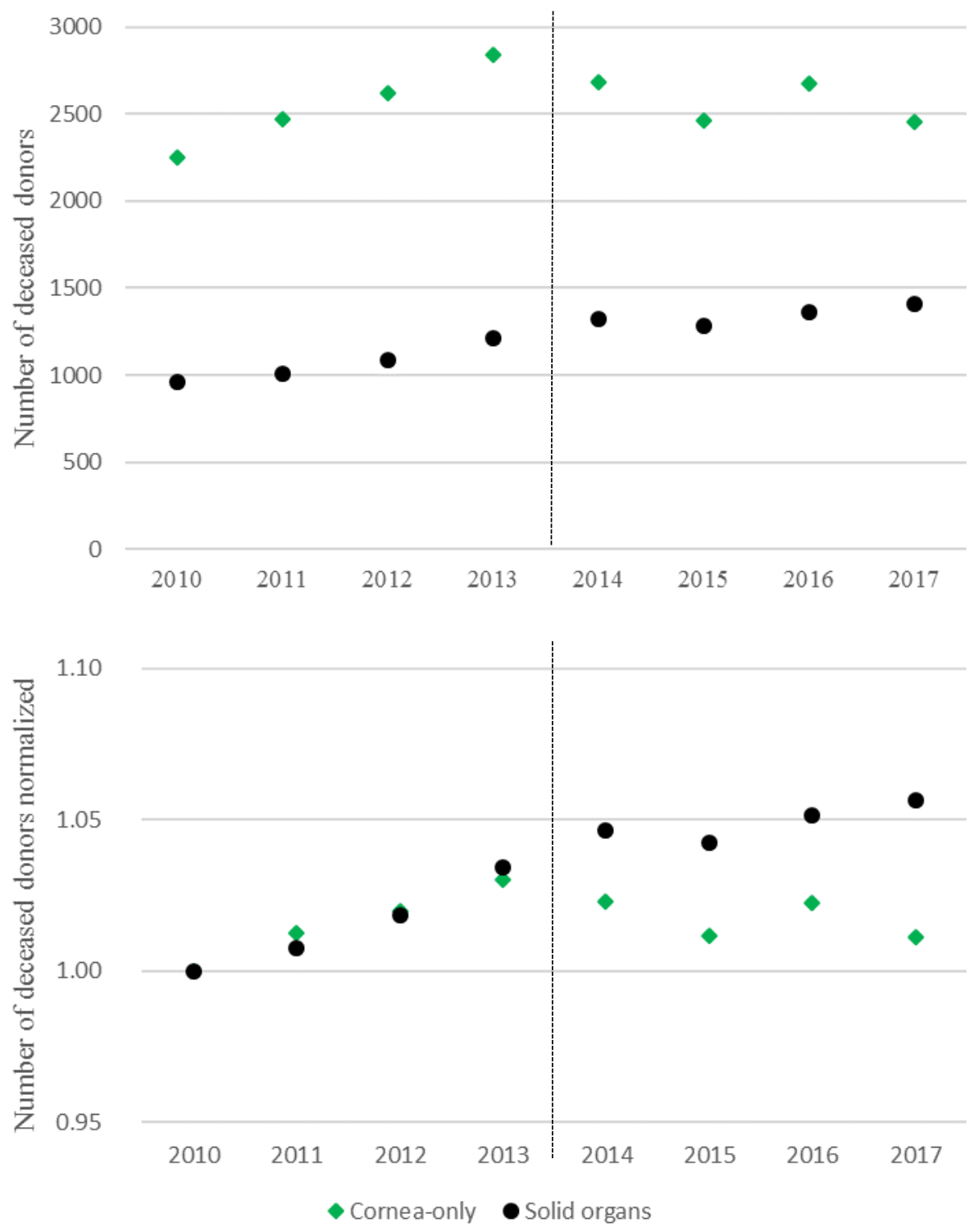

Notes. The upper panel plots the number of deceased solid organ donors (treatment group) and the number of deceased cornea-only donors (control group) by year. In the lower panel, these numbers are normalized to a starting value of one for the year 2010 . The vertical lines indicate the break between the pre-award and post-award periods. 


\section{Figure 3. Unwillingness of Registered Donors to Donate Specific Organs}

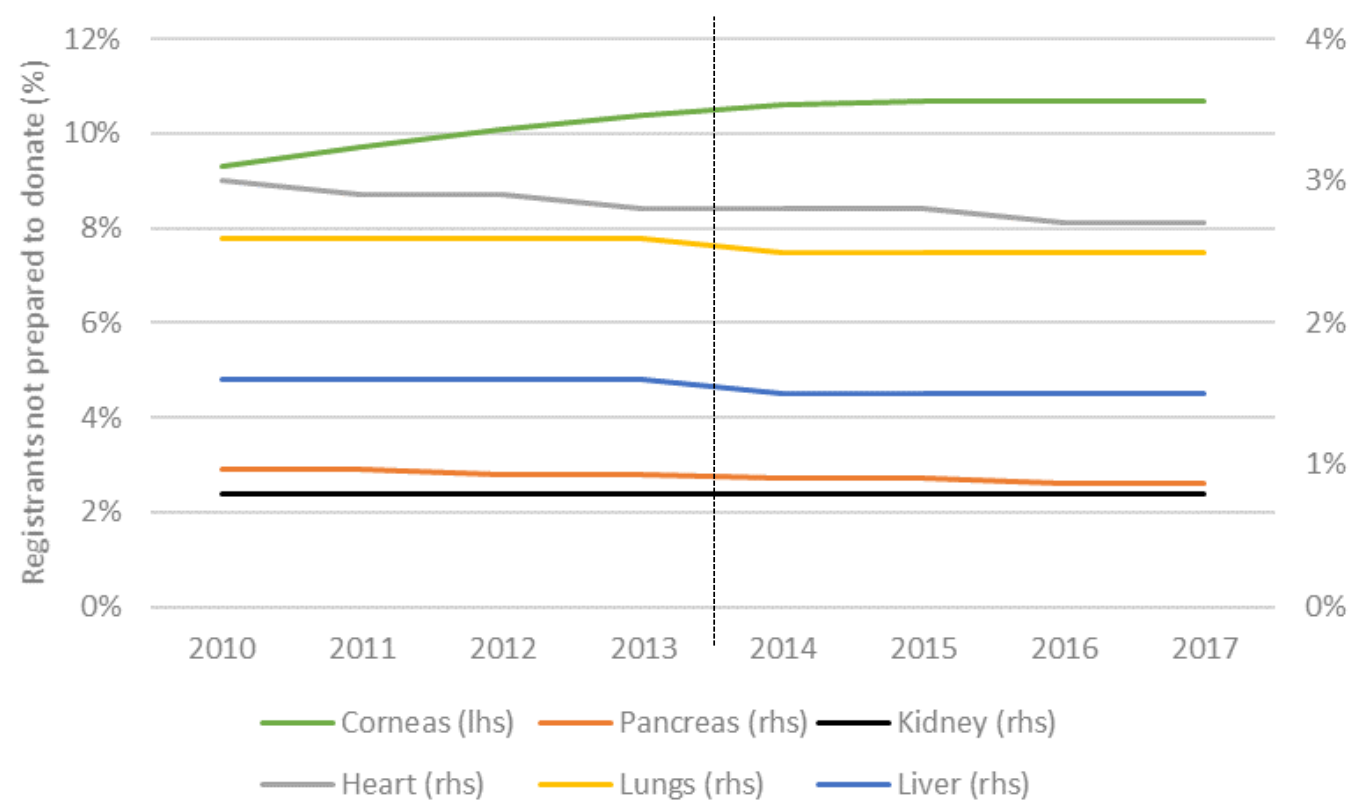

Notes. This figure plots by year the percentages of registered donors that are not willing to donate a specific organ. Cornea restrictions are measured on the left-hand axis and solid organ restrictions are measured on the right-hand axis. The vertical line indicates the break between the pre-award and post-award periods. 
Table 1. Estimated Impact of Award on Deceased Donors

\begin{tabular}{lcc}
\hline & \multicolumn{2}{c}{ Natural logarithm of deceased donors } \\
& Full sample & Excluding Wales \\
\hline Treatment group $\times$ Post award & $0.222^{* *}$ & $0.226^{* *}$ \\
Treatment group & $(0.078)$ & $(0.079)$ \\
& $-0.869 * * *$ & $-0.893 * * *$ \\
Post award & $(0.071)$ & $(0.072)$ \\
& 0.012 & 0.018 \\
Constant & $(0.055)$ & $(0.055)$ \\
& $7.838^{* * *}$ & $7.800^{* * *}$ \\
Observations & $(0.049)$ & $(0.048)$ \\
$R$-squared & 16 & 16 \\
\hline
\end{tabular}

Notes. This table presents the results of a difference-in-differences regression of the (log) number of deceased organ donors over the sample period 2010 to 2017. Post award is an indicator variable that takes the value of one for each year that the award system is in place $(2014,2015,2016$, and 2017), and zero otherwise $(2010,2011,2012$, and 2013). Treatment group is an indicator variable equal to one for solid organ donors and zero for cornea-only donors. Results in the first (second) column include the full sample (exclude data from Wales). Robust standard errors in parentheses. $* * *, * *$ and $*$ indicate statistical significance at the $1 \%, 5 \%$ and $10 \%$ levels, respectively. 
Table 2. Outcome of Solid Organ Donation Process

\begin{tabular}{lcccc}
\hline & Eligible donors & Approached for donation & Family consent rate & Successful donations \\
\hline Pre award & $14.3 \%$ & $64.3 \%$ & $56.6 \%$ & $68.7 \%$ \\
Post award & $15.8 \%$ & $57.7 \%$ & $60.4 \%$ & $68.1 \%$ \\
\hline
\end{tabular}

Notes. This table presents the proportion of eligible donors over audited deaths, the proportion of eligible donors whose family was approached for donation, the family consent rate, and the percentage of cases where solid organs were successfully retrieved following family consent. Averages for Pre 2013 award are computed over the years 2011, 2012, and 2013, while averages for Post award are computed over the years 2014, 2015, 2016, and 2017. 
Table 3. Estimated Impact of Award on Unwillingness to Donate

\begin{tabular}{lccccc}
\hline & Kidneys & Pancreas & Heart & Lungs & Liver \\
\hline Treatment group $\times$ Post award & -0.079 & $-0.152^{* *}$ & $-0.132^{*}$ & -0.118 & $-0.143^{*}$ \\
& $(0.079)$ & $(0.072)$ & $(0.071)$ & $(0.079)$ & $(0.079)$ \\
Treatment group & $-2.512^{* * *}$ & $-1.242^{* * *}$ & $-1.225^{* * *}$ & $-1.334^{* * *}$ & $-1.819^{* * *}$ \\
& $(0.061)$ & $(0.057)$ & $(0.056)$ & $(0.061)$ & $(0.061)$ \\
Post award & $0.258^{* * *}$ & $0.258^{* * *}$ & $0.258^{* * *}$ & $0.258^{* * *}$ & $0.258^{* * *}$ \\
& $(0.064)$ & $(0.064)$ & $(0.064)$ & $(0.064)$ & $(0.064)$ \\
Constant & $7.496^{* * *}$ & $7.496^{* * *}$ & $7.496 * * *$ & $7.496^{* * *}$ & $7.496^{* * *}$ \\
& $(0.053)$ & $(0.053)$ & $(0.053)$ & $(0.053)$ & $(0.053)$ \\
Observations & 16 & 16 & 16 & 16 & 16 \\
$R$-squared & 0.997 & 0.991 & 0.991 & 0.991 & 0.995 \\
\hline
\end{tabular}

Notes. This table presents the results of difference-in-differences regressions of the (log) number of registered donors unwilling to donate a particular organ over the sample period 2010 to 2017. Post award is an indicator variable that takes the value of one for each year that the award system is in place $(2014,2015,2016$, and 2017), and zero otherwise (2010, 2011, 2012, and 2013). The respective Treatment group is indicated in the heading of each column. In all regressions, the control group is the (log) number of all registrants that are not prepared to donate their corneas. Robust standard errors in parentheses. $* * *, * *$ and $*$ indicate statistical significance at the $1 \%, 5 \%$ and $10 \%$ levels, respectively. 